The U.S. Department of Energy's (DOE) Federal Energy Management Program (FEMP) facilitates the Federal Government's implementation of sound, cost-effective energy management and investment practices to enhance the nation's energy security and environmental stewardship.

The General Services

PIX 16425

\title{
UESC SUCCESS STORY: GSA AND CONSOLIDATED EDISON'S STRONG PARTNERSHIP HAS MANY REWARDS
}

Federal Building is 100 percent powered by renewable energy due to projects financed

through utility energy services contracts.

The Federal utility partnership between the General Services Administration's (GSA) Northeast and Caribbean Region and their serving utility, Consolidated Edison (Con Edison), is standing the test of time. Since the early 1990s, GSA has pursued its energy goals by partnering with Con Edison. The utility provides a wide array of programs and services to property management and regional office teams, including comprehensive energy audits, demand response programs, rebates, energy awareness efforts, and advanced meters.

These broad offerings help GSA ensure that it meets, or even exceeds, energy reduction requirements of the Energy Independence and Security Act (EISA) of 2007. Con Edison's continued commitment to providing customer-oriented programs and services means GSA can also rely on the utility to achieve the goals of pending energy legislation.

\section{The Ted Weiss Federal Building}

The Ted Weiss Federal Building showcases the strength of this partnership. The building, a 30-story GSA-owned building in lower Manhattan, features 1.3 million gross square feet consisting mostly of office space with a parking garage on the lower level. The building receives both electric and steam services from Con Edison. The steam is converted to hot water for heating and driving the chiller turbines for cooling.

Many energy-reducing or energy-sensitive operational design decisions were made at conception to allow the building's mechanical systems to operate at maximum efficiency. These decisions include:

- Make-up water: Condensate from chillers is reused as make-up water for cooling towers.
- Thermal insulation: Additional thermal insulation specified for opaque areas of the building's façade reduces heating and cooling loss.

- Variable speed drives: Efficiency of all fans, pumps, and motors is optimized by variable speed drives.

- Energy management system: The fully-automated system uses direct digital controllers for integrated energy management control building wide. This includes heating, ventilation, and air conditioning (HVAC); lighting; valve settings; temperature controls; and operating sequencing.

In addition to energy efficiency measures, the Ted Weiss Federal Building is a green building 100 percent powered by renewable energy - far exceeding the goals of both the Energy Policy Act (EPAct) of 2005 and EISA 2007. This is done by purchasing green power from biomass plants and wind farms in upstate New York through Con Edison's retail access and deregulation program. The Ted Weiss Federal Building is among the first GSA-owned and operated facilities in New York to participate in this program, purchasing green and non-green electricity from a third party energy provider.

GSA also utilized a versatile and proven contracting method, the GSA areawide contract for utility energy services, to have Con Edison perform a study in pursuit of Leadership in Energy and Environmental Design (LEED ${ }^{\circledR}$ ) Gold rating in the Existing Buildings Operations and Maintenance (EBOM) category.

The GSA areawide contract has been used at this facility to implement:

- $\mathrm{CO}_{2}$-based demand control ventilation: $\mathrm{New} \mathrm{CO}_{2}$ sensor signals are used to modulate the HVAC dampers to open or close depending if more or less outdoor air is needed on a floor. 


\section{- Hot water control valves for northern exposure radiant} heating zones: The baseboard finned-tube heating coils on the building's northern exposure lacked control valves, which led to overheating and simultaneous heating/cooling of these zones. The new, self-contained thermostatic control valves on all 30 floors automatically close in response to space temperature, reducing the amount of heating energy consumed.

- Secondary pumping for chilled water plant: New 20 horsepower pumps were installed, instead of the normal 125 horsepower pumps, to maintain constant flow through the chillers.

- Non-hazardous light emitting diode (LED) lighting: In 2008, 91 LED fixtures were installed to replace 182 T-8 fluorescent fixtures in the building's garage. These fixtures consume 55 watts per fixture and are expected to reduce facility energy consumption by 56,457 kilowatt-hours and annual electricity costs by approximately $\$ 9,880$. The new fixtures contain no hazardous materials and are predicted to have a 100,000 hour life.

\section{Advanced Metering}

EPAct 2005 requires advanced metering for electricity and EISA 2007 boosts the requirement to include advanced metering for natural gas and steam. Once again, GSA turned to its long-standing utility partner to determine the role they could play, as recommended in the U.S. Department of Energy's (DOE) Federal Energy Management Program (FEMP) metering guidance. Capitalizing on Con Edison's significant experience and expertise in advanced metering, GSA awarded a contract for all necessary metering for the Ted Weiss Federal Building. The installation software communication protocols, which are integrated with the metering hardware, allow GSA personnel to collect and analyze the building's energy usage, providing a better tool for GSA property management to operate the facility efficiently.

\section{Demand Response Programs}

The energy-efficient design of the Ted Weiss Federal Building made GSA eligible for $\$ 2,384,899$ in energysavings rebates from Con Edison, including \$1,700,000 from the chillers alone. The building's design also allowed GSA to participate in several Con Edison curtailment and demand response programs.

The Ted Weiss Federal Building is enrolled in both Con Edison's Distribution Load Relief Program and
Emergency Demand Response Program, requiring the building to shed demand depending on Con Edison load requirements. In the summer of 2006, one of the hottest summers on record, the building shed 289 kilowatt-hours in July and 5,935 kilowatt-hours in August. This was done by shutting down one elevator bank after normal hours and reducing lobby lighting levels.

Participation in the curtailment program delivered rebates to GSA while shedding crucial kilowatts and kilowatthours in hot summer months when Con Edison is doing its utmost to keep the power flowing for the citizens of New York.

\section{Energy Awareness}

To raise awareness for energy management, GSA staged an energy awareness event on Earth Day 2008 in partnership with Con Edison and the Environmental Protection Agency. More than 15 energy vendors highlighted services and products that can help Federal agencies meet required energy reduction mandates within EISA 2007. Events like this encourage Federal agency tenants to lead by example by reducing energy consumption.

\section{Results}

The facility's overall savings are impressive, $\$ 256,000$ in annual energy costs and 64,872 Btu per gross square foot. This places GSA's Region 2 in the upper tier in energy reduction.

The energy savings success resulting from the GSA and Con Edison partnership also led to a long list of accolades and awards. Among the awards, the Ted Weiss Federal Building received the New York Excellence in New Construction Building of the Year when first constructed and was recognized as the 2008 Middle Atlantic Region Building of the Year and Government Building of the Year. GSA also notes that the facility proudly displays its ENERGY STAR ${ }^{\circledR}$ Label being the nation's first to receive the designation in 1999 and receiving recertification in 2006.

GSA acknowledges the major role its utility partner, Con Edison, played in helping the agency make its energy goals a reality. Both partners value this important collaboration. GSA can rely on Con Edison to help meet its mandated and strategic energy management goals, while Con Edison is rewarded with a customer always striving to use precious energy resources wisely and minimize demand. Both partners are always willing to lead by example.
For additional information please contact: EERE Information Center 1-877-EERE-INF (1-877-337-3463) www.eere.energy.gov/informationcenter Printed with a renewable-source ink on paper containing at least $50 \%$ wastepaper, including $10 \%$ post consumer waste.
Prepared by the National Renewable Energy Laboratory (NREL) a nationa laboratory of the US. Depart Energy Office of Energy Efficiency and Renewable Energy; NREL is operated by the Alliance for Sustainable Energy, LLC.

DOE/GO-102009-2899 • July 2009 